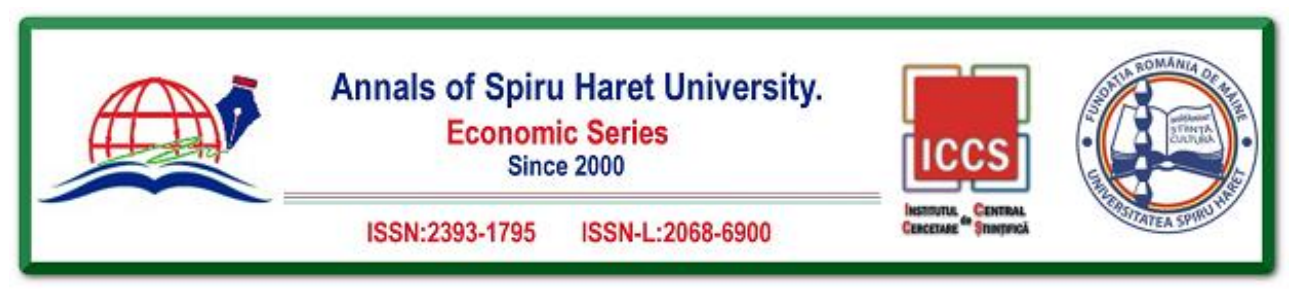

Issue 4/2018

\title{
THE DEVELOPMENT OF THE TRAVEL AND TOURISM INDUSTRY IN THE WORLD
}

\author{
Bogdan SOFRONOV ${ }^{1}$ \\ ${ }^{1}$ University Politehnica of Bucharest, 313 Splaiul Independenței, \\ Bucharest, 060042, Romania, Email: bogdansofronov@yahoo.com
}

How to cite: SOFRONOV, B. (2018). "The Development of the Travel and Tourism Industry in the World." Annals of Spiru Haret University. Economic Series, 18(4), 123-137, doi: https://doi.org/10.26458/1848

\begin{abstract}
The purpose of this paper is to see how the travel and tourism industry is changing and its development in the world.

Travel and tourism industry is one of the world's greatest industrial sectors. It drives economic growth, creates jobs, improves social development and promotes peace.

Hundreds of millions of people around the world are dependent on the sector for their employment. In some island economies, travel and tourism industry is not just the biggest employer; it is effectively the only employer. The role is to contribute to the creation of sustainable economies.

Travel and tourism industry is a diverse sector consisting of millions of companies and employers, from the biggest global travel brands to the smallest tour operators or hostel owners. Together, we form a formidable force with a voice to be heard at the highest levels of society and government.
\end{abstract}

Keywords: development; travel; tourism; tourism industry; international tourism.

JEL Classification: Z30, Z32

\section{Introduction}

From an economic and social point of view, the development of travel and tourism industry is reflected in an increasing demand of the population for an ever-increasing 


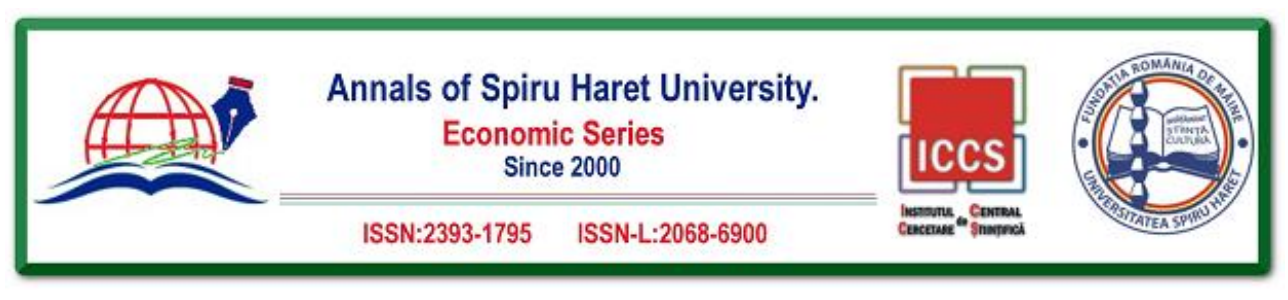

\section{Issue 4/2018}

range of consumer goods and services, a demand that stimulates the manufacturing and service sectors, leading to an increase in economic activity and consumption, independent of the normal evolution of market trends. As a consequence, this increase in tourism consumption, caused by massive seasonal movements of the population towards certain destinations of tourist interest and increasing the number of visitors, is favourable to the complex development of the economy of some tourist areas and of the economic ensemble of the countries which are developing their tourism industry.

In other words, in line with the increase in the demand for tourist services, a distinct offer of services has gradually developed, whose volume and structures imposed the organization and continuous improvement of an economic and organizational program able to guide the services provided by tourists. According to the steps, a tourist travels from the permanent residence to the destination and back, e.g. there is a complex of activities designed to meet the various consumption needs.

The growing volume and complexity of tourism services have generated the development of a real tourist industry that justifies treating the phenomenon of tourism as a distinct branch of the growing economy in the world. By its nature, the tourism phenomenon is a particularly complex, with profound social, political, cultural and economic implications. Unlike other service sectors, the tourism industry remains a consequence whose development at each stage can only be ensured in close correlation with the levels of development of other branches of the world economy.

\section{Literature Review}

My research paper entitled: The development of the travel and tourism industry in the world, is written after I've documented on the basis of the following published articles:

1. "Development of Tourism Industry and National Economic Security" written by Kusubakti Andajani, Yuni Pratiwi, Sri Yati, and Sri Indrawati, published in Journal of Business and Management Sciences.

2. "A Review of Green Development in the Tourism Industry" written by Tang Chengcai, Zheng Qianqian, Qin Nana, Sun Yan, Wang Shushu and Feng Ling, published in Journal of Resources and Ecology.

3. "The Role of Development of Transport Tourism in Economic Growth" written by Flora Alasgarova, published in Annals of Spiru Haret University. Economic Series.

4. "Importance of Training and Development in Tourism Industry" written by Sandeep Malik, published in International Refereed Journal of Reviews and Research. 


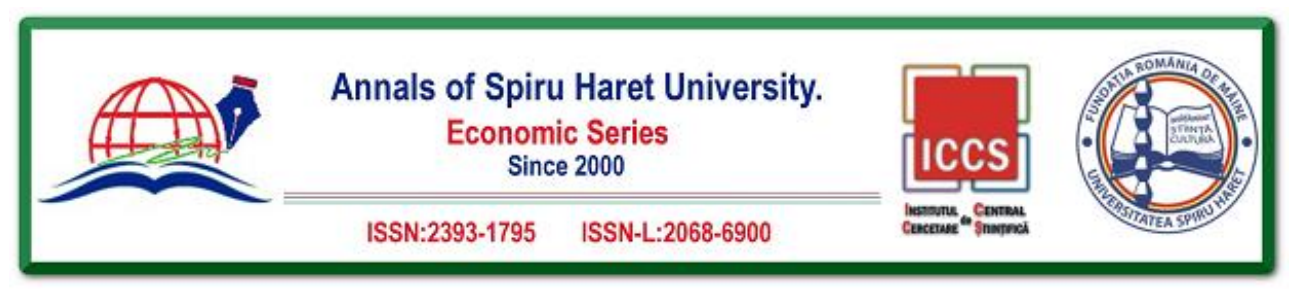

Issue 4/2018

\section{The Development of the Travel and Tourism Industry}

The travel and tourism industry is one of the largest and fastest growing sectors in the world, with economic growth in 2017 (4.6\%) outpacing that of the global economy (3\%) for the seventh year in a row, as well as all other major industrial sectors. This means that travel and tourism industry GDP growth was 50\% higher than that of the global economy. In the same year, it employed 313 million people across the world, equivalent to 1 in 10 jobs, and generated $10.4 \%$ of global gross domestic product (GDP). [ICAO, 2018]

In 2017, there were 1.322 billion international tourist arrivals - an increase of $7 \%$ compared to the previous year, and the strongest growth rate for seven years. [ICAO, 2018]

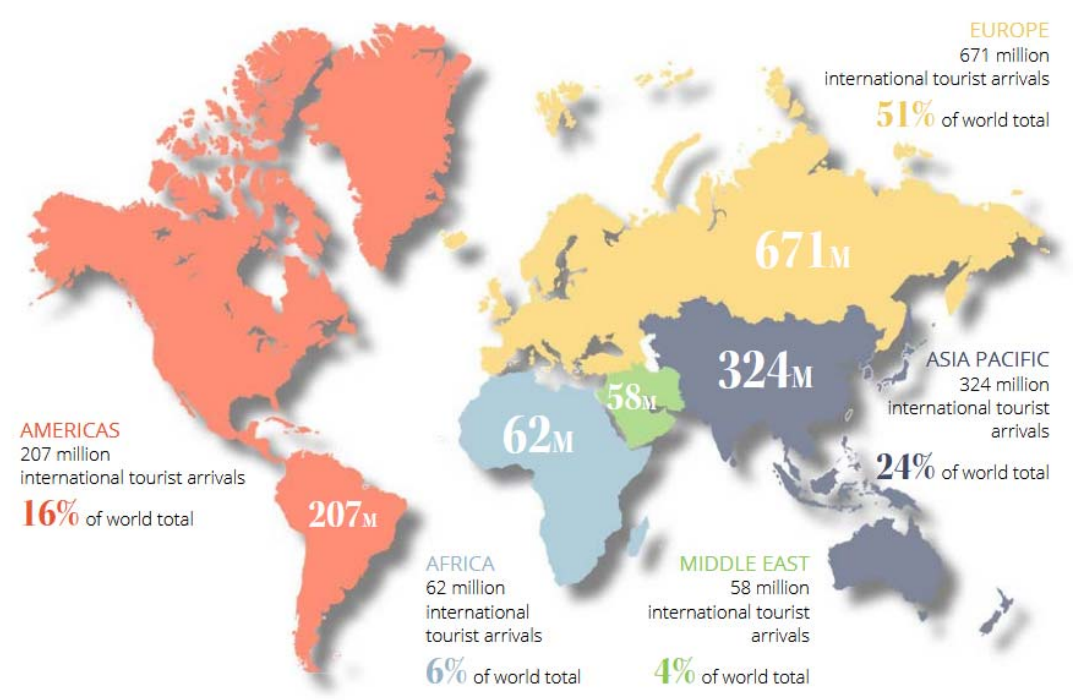

Fig. 1. International Tourist Arrivals in 2017

Source: ICAO (2018), "Travel and Tourism a Force for Good in the World,” accessed November 7, 2018,

https://www.icao.int/Meetings/iwaf2018/Documents/Travel\%20and\%20Tourism.pdf

By 2030, it is estimated that there will be 1.8 international tourist arrivals which means an average of 5 million people crossing international borders every single day. [ICAO, 2018] 


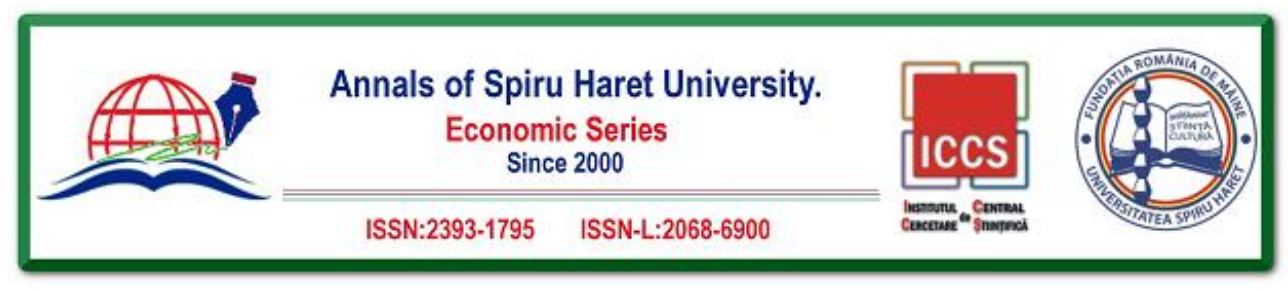

\section{Issue 4/2018}

As powerful as the travel and tourism sector is in terms of its reach and economic impact, it is unique in the diversity of its composition. Stakeholders in travel and tourism range from global hotel chains, cruise lines and seaports, and airports and airlines turning over billions of dollars every year, to individuals running a bed and breakfast, teaching a cooking class or leading a tour through their local community. Thinking of the industry in such a way allows us to picture not only the vast economic impact that it has at the global level, but also to consider the life-transforming effects it can have on real people in destinations across the world. [ICAO, 2018]

Looking to the next decade, 100 million new jobs could be created in the travel and tourism sector by 2028 - 64.5 million of these will be in the Asia Pacific region, with 35 million in China and 10 million in India. [ICAO, 2018]

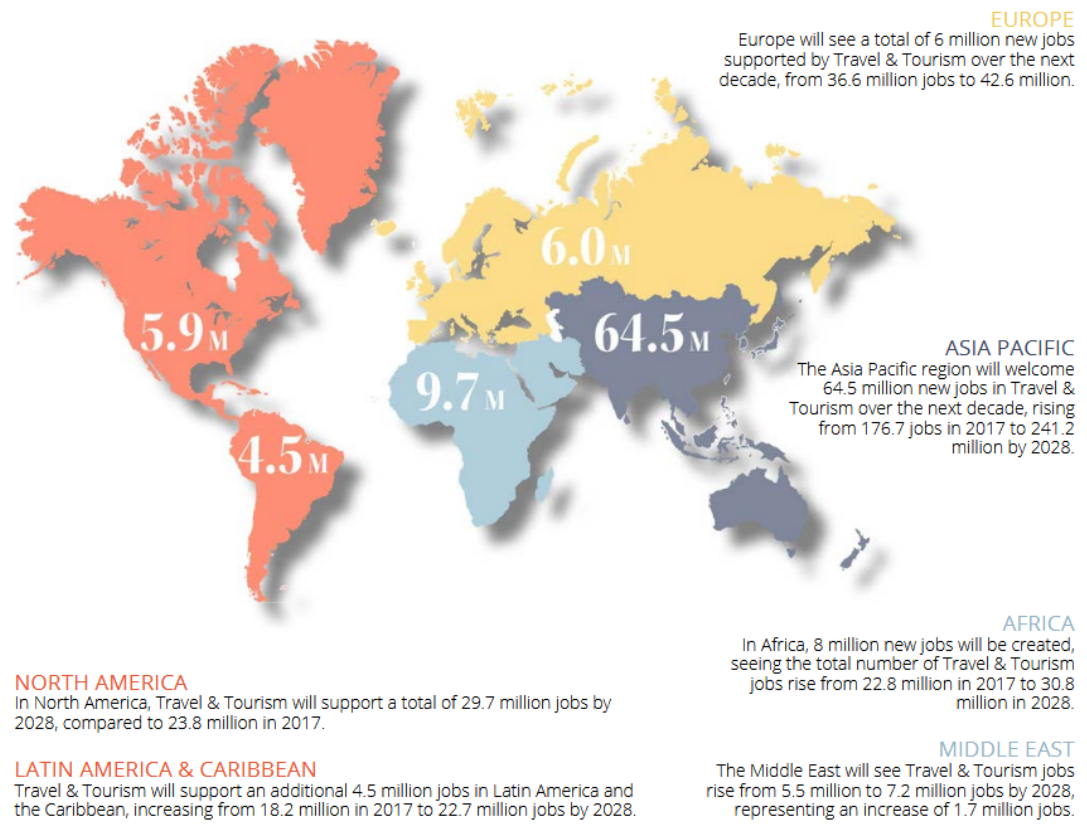

Fig. 2. Regional Breakdown of Total Job Creation (Millions) from 2017 to 2028

Source: ICAO (2018), “Travel and Tourism a Force for Good in the World,” accessed November 7, 2018,

https://www.icao.int/Meetings/iwaf2018/Documents/Travel\%20and\%20Tourism.pdf 126 


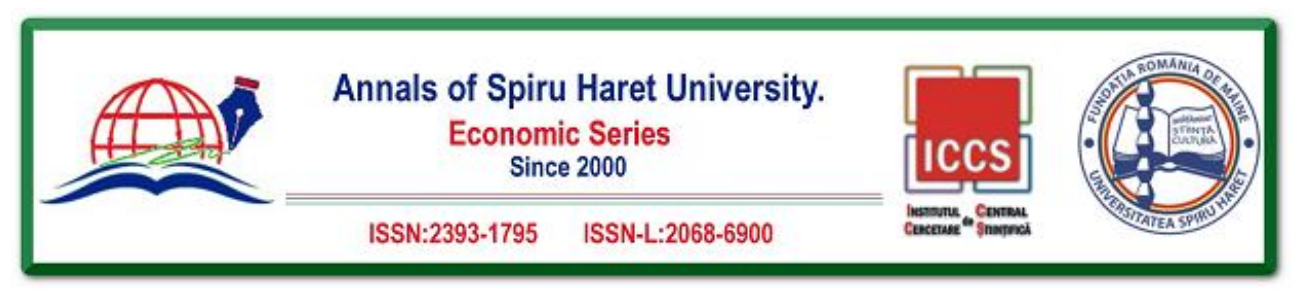

Issue 4/2018

The travel and tourism sector accounted for $10.4 \%$ of global GDP and 313 million jobs, or 1 in 10 jobs globally in 2017. With 4.6\% GDP growth in 2017 - the highest rate since 2011 - the travel and tourism sector outperformed all other major global economic sectors, with manufacturing coming in second place with $4.2 \%$, and financial services lagging behind with $2.5 \%$ industry sector growth. [ICAO, 2018]

With the right regulatory and policy environment, including support from governments, travel and tourism industry has the potential to create tens of millions of new jobs by 2028. [ICAO, 2018]

The travel and tourism industry grew faster in 2017 than every other major economic sector, including financial services. [ICAO, 2018]

The USA received the greatest direct and total contribution to GDP from travel and tourism industry with $\$ 509.4$ billion and \$1501.9 billion respectively in 2017 . China is forecast to overtake in both categories by 2028. [ICAO, 2018]

According to aviation, a new record was established - 4.1 billion passengers were carried by the aviation industry on scheduled services in 2017, indicating a 7.1\% increase over 2016. This figure is expected to almost double by 2036, with 7.8 billion people predicted to be travelling by air each year, 55\% of international tourists travel to their destination by aircraft. [ICAO, 2018]

Cruise travel is on the rise, with 27.2 million passengers expected to set sail in 2018. In 2017, 25.8 million passengers cruised, representing 4.5\% growth on 2016. [ICAO, 2018]

Overall growth in the cruise industry (64\%) has exceeded that of the general global tourism sector (45\%) over the past 10 years. [ICAO, 2018]

In 2017, the hotels and resorts industry generated $\$ 878$ billion in revenue and employed 4.3 million people. [ICAO, 2018]

The travel and tourism industry directly contributed \$2.6 trillion - equivalent to the size of the UK economy - to global GDP in 2017, or 3.2\% of global GDP. [ICAO, 2018]

In 2017, travel and tourism industry's total (including direct, indirect and induced impacts) contribution to global GDP was $\$ 8.3$ trillion, equivalent to 10.4\%. [ICAO, 2018]

International tourism receipts calculated as expenditure by international visitors on accommodation, food and drink, entertainment, shopping and other services and goods, amounted to $\$ 1.22$ trillion in 2017. [ICAO, 2018]

Travel and tourism industry is a major contributor to international trade in services, with global visitor exports, the amount brought as a contribution by visitors to the country they visit generating a record $\$ 1.5$ trillion in 2017. This is equivalent 


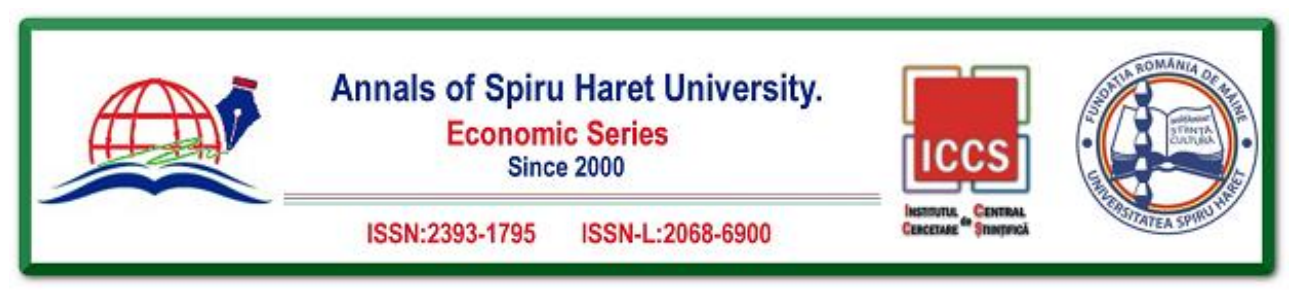

\section{Issue 4/2018}

to an average of $\$ 4$ billion a day, almost $7 \%$ of total exports and $30 \%$ of total world services exports. Global visitor exports should grow by $3.9 \%$ in 2018 , and by $4.1 \%$ per year from 2018 to 2028, totalling $\$ 2.3$ trillion in 2028, and making up 6.9\% of total exports. [ICAO, 2018]

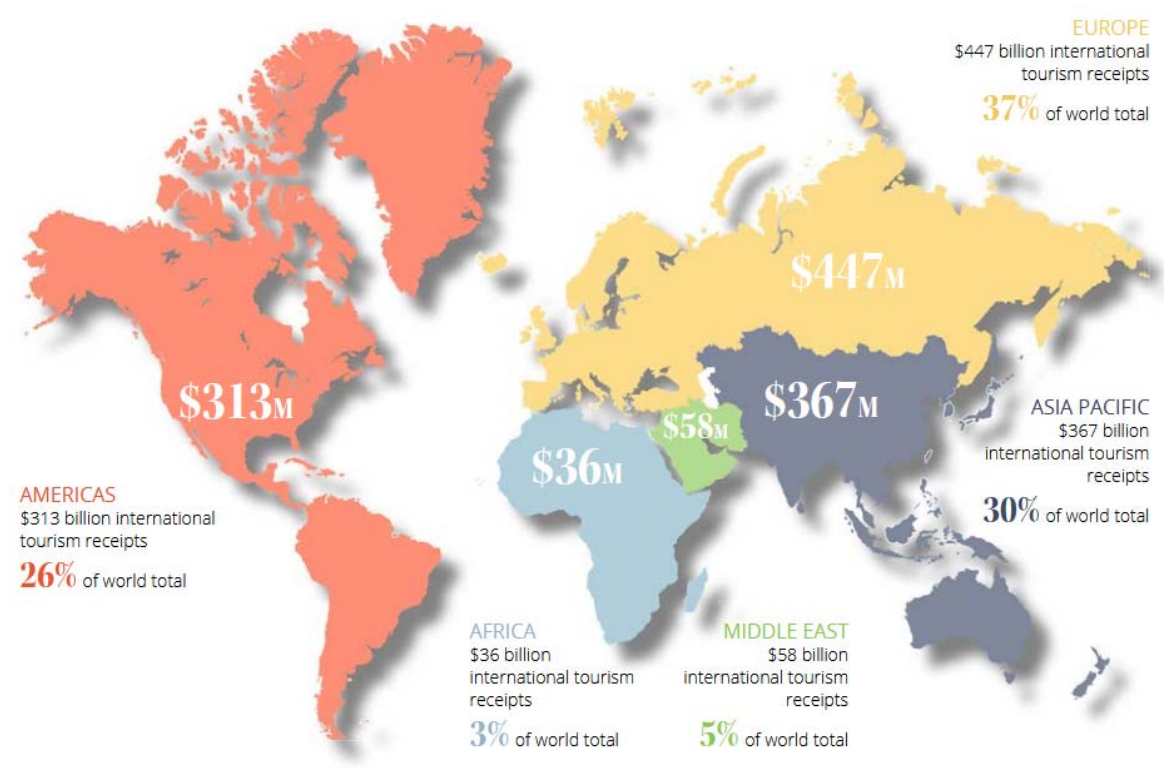

Fig. 3. International Tourism Receipts in 2017

Source: ICAO (2018), "Travel and Tourism a Force for Good in the World,” accessed November 7, 2018,

https://www.icao.int/Meetings/iwaf2018/Documents/Travel\%20and\%20Tourism.pdf

The travel and tourism industry yields significant economic and social benefits around the world, and possesses the power to change people's lives for the better by driving economic growth and development, reducing poverty through the provision of livelihoods, and fostering tolerance and peace through intercultural exchange and understanding. The sector has demonstrated strong and continued growth in the number of people travelling internationally each year, as well as its economic impact over the last six decades. Future predictions suggest that the sector will continue to grow in size and significance, amplifying its opportunity and responsibility to act as a force for good in the world. [ICAO, 2018] 


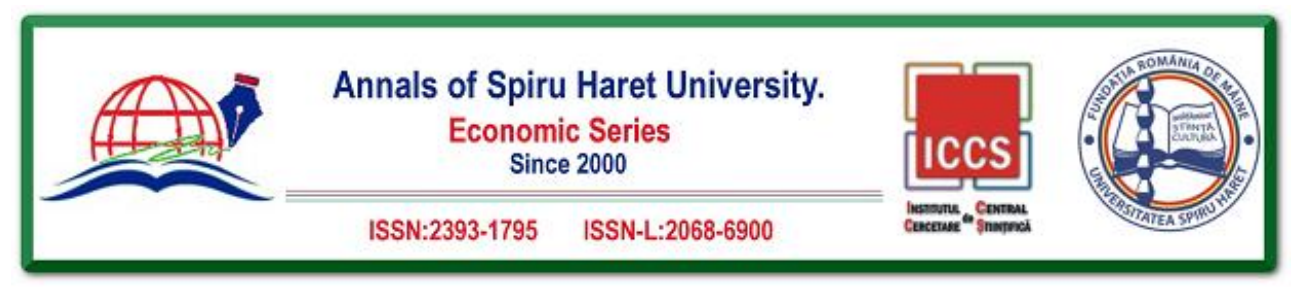

Issue 4/2018

While strong, sustained and diversified growth in travel and tourism industry is positive, high growth rates require all stakeholders at destinations to consider how to grow tourism responsibly and sustainably. Successful sustainable tourism strategies should move from promotion to broader destination planning and management, and look to the long-term to ensure quality engagement, preservation of natural and cultural resources, and the spread of tourism benefits to all. [ICAO, 2018]

The travel and tourism sector requires the hotels and resorts industry to provide accommodation for people visiting new destinations, and the revenue his generates contributes to the sector as a whole. In 2017, the industry generated $\$ 878$ billion globally in revenue, and employed 4.3 million people across 739,000 businesses. Over the past five years (to 2017), they estimate that the industry has grown by $3.2 \%$ per year, thanks to improved global economic conditions and the resulting boost to consumer confidence and increased travel. [ICAO, 2018]

It is estimated that the hotel industry is comprised of 17.2 million rooms, and that branded hotels have 53\% of the market. The leading branded hotel companies, including IHG, Marriott, Hilton, Wyndham and Accor Hotels account for nearly one quarter of the total open branded rooms [ICAO, 2018]

In line with the travel and tourism sector as a whole, the hotels and resorts industry expects growth in the future thanks to improving global economic conditions resulting in higher GDP and more disposable income, as well as demographic shifts such as the growth of the middle class and an ageing population that has the desire and means to travel. [ICAO, 2018]

Travel and tourism industry and its related industries clearly contribute to the economic and social development of a nation, by driving economic growth, creating jobs and wealth, fostering trade and encouraging investment. The emergence of a tourism sector within a country offers the opportunity to acquire business or language skills thanks to newly realised entrepreneurial and other professional opportunities, resulting in human capital development, and upward social mobility. [ICAO, 2018]

The travel and tourism industry investment in 2017 was $\$ 882$ billion, or $4.5 \%$ of total investment. It should rise by $4.8 \%$ in 2018 , and by $4.3 \%$ over the next ten years, reaching \$1,408.3 billion in 2028 (5.1\% of total). [World Travel and Tourism Council, 2018]

As the world becomes more connected and more focused on travel and tourism industry, innovative business models become crucial to the development of tourism. At the same time, particular attention must be paid to the challenges and threats that characterize the development and growth of the tourism industry. 


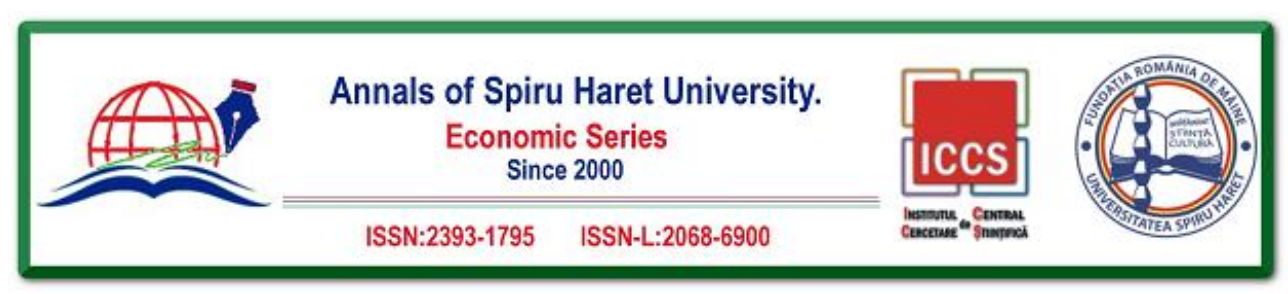

\section{Issue 4/2018}

\section{New Technology Trends in the Travel and Tourism Industry}

The advent of technology is fostering a change in the travel and tourism industry regarding how companies interact with customers. Consequently, travel companies are adopting various technologies to improve operational efficiencies and meet customers' expectations. [Global Data, 2018]

The trends to watch out for in the travel and tourism industry in 2018 are [Global Data, 2018]:

- Augmented and Virtual Reality (AR and VR): The past few years have seen an increase in AR or VR popularity among travel and tourism companies, and the trend is set to continue. These technologies are being used either for content marketing or to enhance the customers' experiences. For example, airlines have started using VR technology to show travellers the cabins in advance, in order to increase ticket or ancillary services sales.

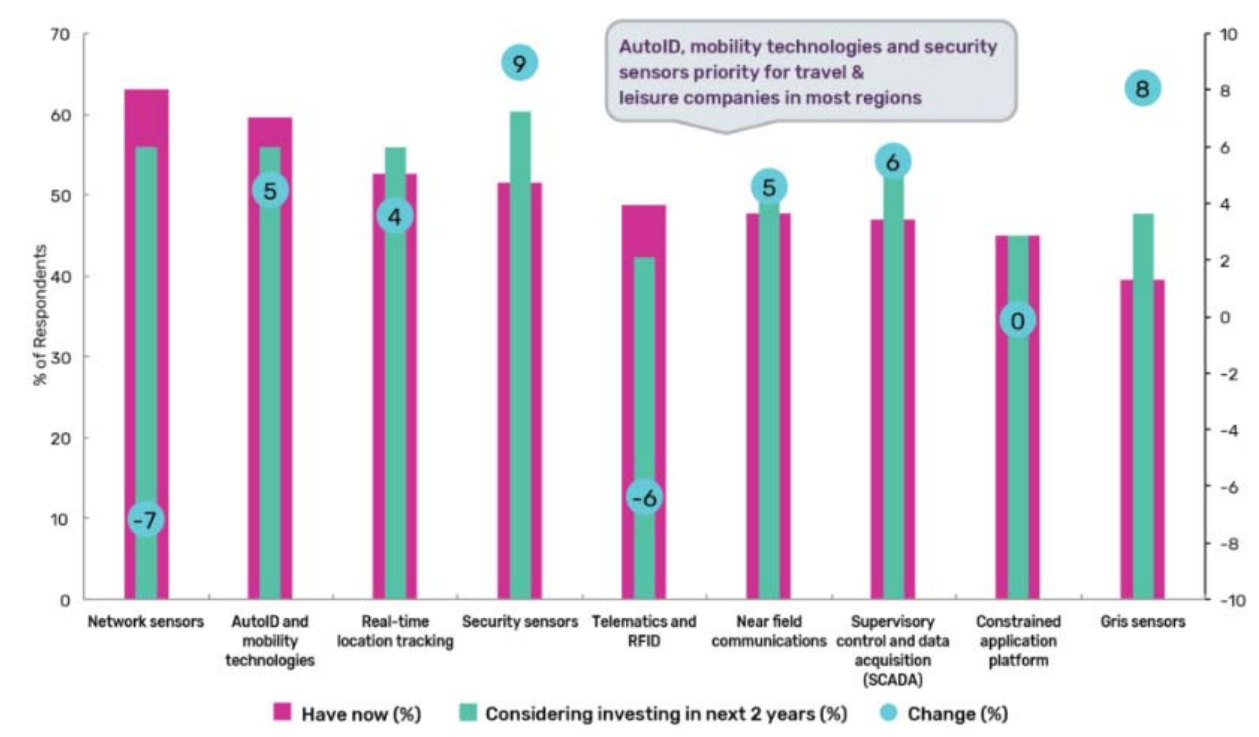

Fig. 4. Internet of Things Solutions

Source: Global Data (2018), “Top 6 Technology Trends to Watch out for in the Travel and Tourism Industry in 2018,” accessed November 8, 2018, https://www.globaldata.com/top-6technology-trends-watch-travel-tourism-industry-2018/ 


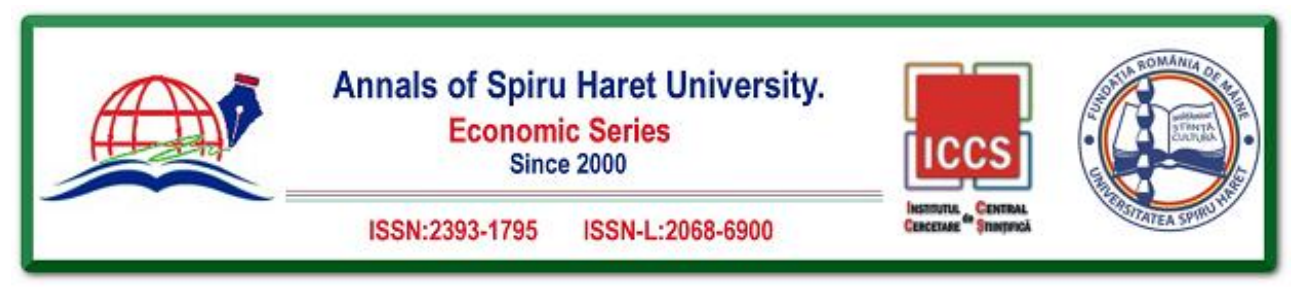

Issue 4/2018

-Artificial Intelligence (AI): AI is behind many evolving technologies and innovations in the travel and tourism sector. The ways in which it helps the industry can be classified into three major categories: Machine Learning, ChatBots or TravelBots, and Robots. Thanks to AI, operations which usually require human intervention and a lot of time to learn new skills can be automated, thus speeding up processes, while improving quality and performance, and decreasing costs.

-Internet of Things (IoT): IoT has a lot of potential to shape the future of the travel and tourism industry, and companies have started to realize that. An example of an industry player using IoT to reduce anxiety and stress levels associated with lost bags is Lufthansa. Passengers can track their baggage via a link found on their mobile boarding pass in the Lufthansa app.

- Voice Technology: Voice technology is another digital novelty that is beginning to disrupt the travel and tourism sector, as more and more customers switch from typed-in search to voice interactions. More and more hotels have started experimenting with voice-activated devices.

-Wi-Fi connectivity: When travelling, people want to always be connected, either to get destination ideas, options regarding places to visit or eat, find directions to points of interest, or share their experience with friends via social media or other connectivity platforms. As a result, investing in network services helps companies offer a more seamless and highly personalized experience to customers, boosts operational efficiency, real-time decision making, strengthens the physical (via CCTV) and the cybersecurity, along with data privacy.

-Wearable devices: Despite a sluggish start, travel and tourism companies are gradually using this technology to offer customers a more personalized and united experience. For instance, the Walt Disney Company deployed a wearable, customizable, RFID-equipped MagicBand, which connects to the theme park infrastructure, to reduce waiting times and track guests' locations and activities.

Another is Blockchain, specifically crypto-currencies. This nascent technology, which allows for decentralized and secure storage and sharing of information, has the potential to increase trust while minimizing friction and corruption. [World Economic Forum, 2018]

\section{The Importance of Visitors for Travel and Tourism Industry}

The importance of visitors is a value factor for travel and tourism industry, as the number has increased in 2017, Bangkok was visited by 20 million tourist followed by London with 19.80 million and Paris with 17.50 million. 
Annals of Spiru Haret University.

Economic Series

Since 2000

ISSN:2393-1795

ISSN-L:2068-6900

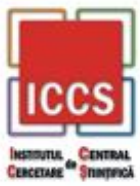

Issue 4/2018

Table 1. Most Visited Destination in the World

\begin{tabular}{|c|c|c|c|}
\hline \multicolumn{2}{|c|}{ Destination in the world } & $\begin{array}{c}\text { Tourist number } \\
\text { in } 2017\end{array}$ & $\begin{array}{c}\text { Growth forecast } \\
\text { for } 2018\end{array}$ \\
\hline 1. & Bangkok & 20 million & $9.8 \%$ \\
\hline 2. & London & 19.80 million & $3.1 \%$ \\
\hline 3. & Paris & 17.50 million & $2.9 \%$ \\
\hline 4. & Dubai & 15.90 million & $5.5 \%$ \\
\hline 5. & Singapore & 13.90 million & $4.0 \%$ \\
\hline 6. & New York & 13.50 million & $4.1 \%$ \\
\hline 7. & Kuala Lumpur & 12.50 million & $7.5 \%$ \\
\hline 8. & Tokyo & 11.90 million & $1.6 \%$ \\
\hline 9. & Istanbul & 10.50 million & $19.5 \%$ \\
\hline 10. & Seoul & 9.50 million & $6.0 \%$ \\
\hline
\end{tabular}

Source: personal contribution

In 2018, the number is estimated to grow with $19.5 \%$ in Istanbul followed by Bangkok with 9.8\% and Kuala Lumpur with 7.5\%.

In other words, there are so many interesting and beautiful places to discover in the world. Some countries have a larger tourism industry than others, but just about all of them have something to offer.

In 2018, the following countries are among the most visited in the world:

1. France with 82.6 million visitors. The most visited places in France are following:

-Eiffel tower in Paris - the most visited city in France;

-St Tropez summer holiday destination;

-Chamonix ski resort;

- Palace of Versailles;

- Mont Saint-Michel.

2. The United States with 75.6 million visitors. Most visited places in the USA are:

- Manhattan in NYC;

-Grand Canyon; 
- Yellowstone National Park with its geysers;

- Golden Gate Bridge in San Francisco;

- Niagara Falls at the borders with Canada.

3. Spain with 75.6 million visitors. Most visited places in Spain are:

- Sagrada Familia in Barcelona;

- Alhambra;

- Mezquita of Cordoba;

-El Escorial;

-Ibiza Island.

4. China with 59.3 million visitors. Most visited places in China are:

- The Great Wall of China in Beijing;

- The Terracotta Army in Xi'an;

- The Forbidden City in Beijing;

- The Li River in Guilin;

- The Yellow Mountains in Huangshan.

5. Italy with 52.4 million visitors. Most visited places in Italy are:

- Grand Canal in Venice;

-Coliseum in Rome;

-Florence Cathedral;

- Piazza del Campo in Siena;

- Pompeii.

6. United Kingdom with 35.8 million visitors. Most visited places in the UK are:

-London;

-Scottish Highlands;

-Stonehenge;

-Edinburgh;

- York.

7. Germany with 35.6 million visitors. Most visited places in Germany are:

-Berlin's Brandenburg Gate;

- Cologne Cathedral;

-The Black Forest;

- Neuschwanstein Castle;

- Miniatur Wunderland.

8. Mexico with 35.0 million visitors. Most visited places in Mexico are:

- Teotihuacán and its huge pyramids; 


\section{Issue 4/2018}

-Chichen Itza - the largest of the Maya cities in the Yucatan Peninsula;

- Tulum - for those looking for ideal beach holidays;

- Copper Canyon - a network of canyons;

- Palenque - an archaeological site.

9. Thailand with 32.6 million visitors. Most visited places in Thailand are:

-Ko Phi Phi;

- Phang Nga Bay;

- Grand Palace, Bangkok;

-Rai Leh;

-Mu Ko Chang National Park.

10. Turkey with 30 million visitors. Most visited places in Turkey are:

-Istanbul;

-Antalya;

- Cappadocia;

-Bodrum;

-Side.

Table 2. Most Visited Countries in the World

\begin{tabular}{|c|c|c|}
\hline 1. & France & 82.6 million visitors \\
\hline 2. & The United States & 75.6 million visitors \\
\hline 3. & Spain & 75.2 million visitors \\
\hline 4. & China & 59.3 million visitors \\
\hline 5. & Italy & 52.4 million visitors \\
\hline 6. & United Kingdom & 35.8 million visitors \\
\hline 7. & Germany & 35.6 million visitors \\
\hline 8. & Mexico & 35.0 million visitors \\
\hline 9. & Thailand & 32.6 million visitors \\
\hline 10. & Turkey & 30 million visitors \\
\hline
\end{tabular}

Source: personal contribution

Other countries with many visitors in 2018 are Greece with 24.8 millions, Japan with 24.0 millions, Canada with 20.0 millions or Singapore with 12.9 millions. 


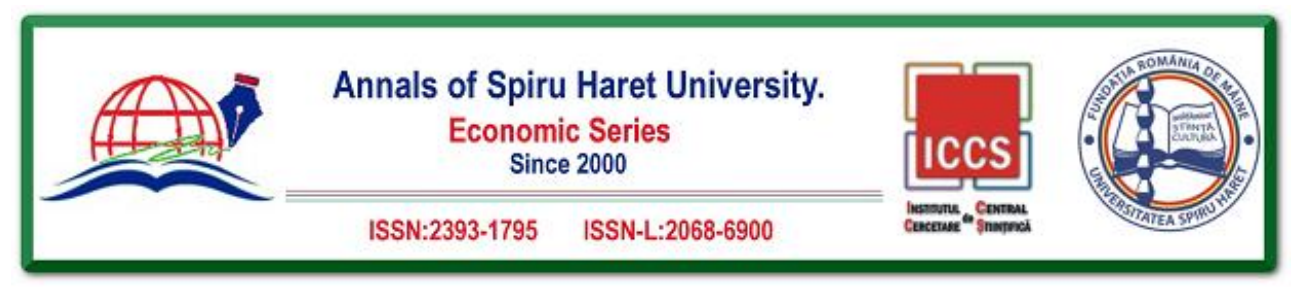

Issue 4/2018

Competition model in a tourism destination is determined by seven factors: colocation, associationism, competition, cooperation, strategic management, coentrepreneurship, and co-production. [Channoi \& Clemes, 2018]

The tourism offer is very important for the business tourism sector, along with the existence of adequate venues, facilities and support services. [Marques, 2017]

Tourism is very closely linked to culture and civilization, among them establishing an interdependent relationship. [Jelev, 2016]

The economic climate along with the economic policies that are applied to the destination could directly or indirectly encourage the development of the tourism sector and thus increase tourism income. [Antonakakis \& Dragouni, 2018]

Tourism offers a combination of products and services which need to be customized based on the preferences of different market segments. [Mehran \& Olya, 2018]

Various big data have been applied to tourism research, making a great improvement. [Li \& Xu, 2018]

Innovation is a critical factor in the success of destinations competing for tourists against other destinations. [Zach \& Hill, 2017]

Tourism has long been claimed as a crucial force shaping globalization, while in turn the developments of the tourism sector are under the influences of growing interdependence across the world. [Song \& Li, 2018]

Travel safety is a critical issue to most tourists, while the peacefulness level of travellers' country of origin is an important key factor for understanding different travel behaviours and safety perceptions held when going on an international trip, namely, regarding involvement, risk and safety/insecurity perceptions. [Seabra \& Kastenholz, 2018]

The biggest risks in the travel and tourism industry at global level are related to geopolitics, terrorism, uncontrolled spread of epidemics, data sharing and security. These risks can have severe repercussions on the tourism industry, whose development depends directly on providing a safe travel experience. Security-related events have had a strong impact on the affected tourist destinations and have been particularly affected by the decrease in the number of tourists and the drastic decrease in revenues from this economic activity. Thus, it focuses on identifying innovations, technological and infrastructure development at local, regional, national level to facilitate travel conditions with improved security measures.

\section{Conclusions}

In conclusion, the travel and tourism industry is very important for most countries in the world, having a prime place in the economy due to the high income it brings. 


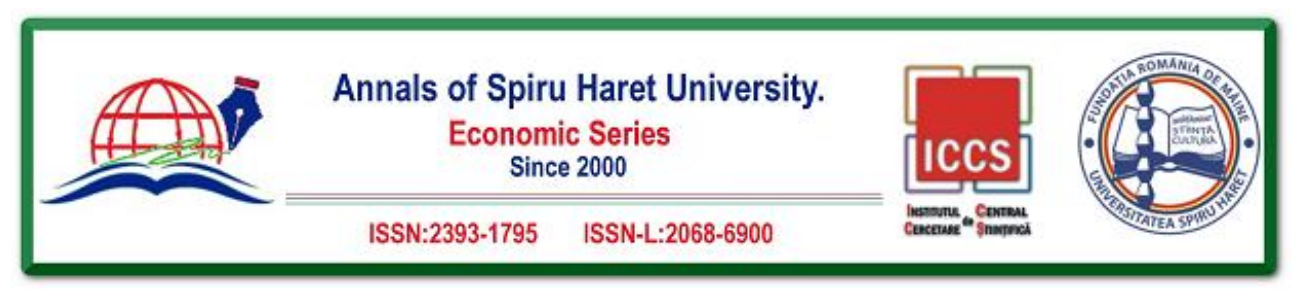

\section{Issue 4/2018}

Tourism development policies in the world are increasingly important for developing countries. Not only have they introduced a new sector into the country's economy, but they have achieved macroeconomic objectives. That is why most countries concentrate their efforts on attracting foreign tourists, in order to increase the country's foreign reserves.

Tourism has a special importance in meeting the material and spiritual needs of the people. It contributes to restoring the body through rest, recreation, movement, balneo-medical treatments, manifests itself as a means of educating people, it favours the exchange of ideas, the knowledge of tourists and the local population.

Tourism also has influences on the environment and its components, both positive and negative, and tourists must learn to protect the environment. At the same time, it acts in the direction of enhancing ties between nations, knowing people and peoples and helping maintain peace in the world.

More and more tourists begin to look for vacations as more than just a break in the office. A journey means opening the mind and gaining new experiences. That's why the number of tourists who want to travel to exotic places is simply growing, just different from what they are accustomed to seeing in the areas where they live and want to see more.

In this case, the new trends in the travel and tourism industry are:

-Responsible and sustainable tourism;

- Wellness tourism;

-Millennial travellers;

-Family holidays;

- Adventure holidays;

-Food tourism;

-To travel single.

\section{References}

1. Antonakakis, N., \& Dragouni, M. (2018). "The Tourism and Economic Growth Enigma: Examining an Ambiguous Relationship through Multiple Prisms.” Journal of Travel Research, dx.doi.org/10.1177/0047287517744671

2. Channoi, R., \& Clemes, M. (2018). "Development of a Tourism Competition Model: A Preliminary Delphi Study." Journal of Hospitality and Tourism Management, https://doi.org/10.1016/j.jhtm.2018.10.004

3. Global Data (2018). "Top 6 Technology Trends to Watch out for in the Travel and Tourism Industry in 2018," accessed November 8, 2018, https://www.globaldata.com/top-6technology-trends-watch-travel-tourism-industry-2018/ 


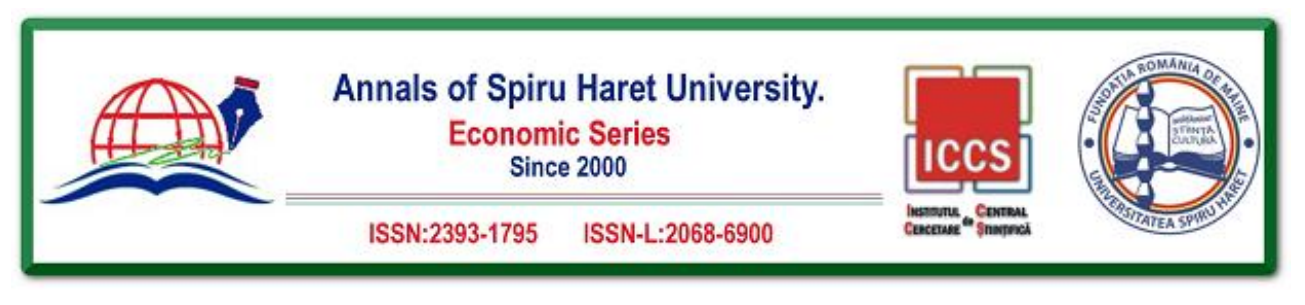

Issue 4/2018

4. ICAO (2018). "Travel and Tourism a Force for Good in the World," accessed November 7, 2018, https://www.icao.int/Meetings/iwaf2018/Documents/Travel\%20and\%20Tourism.pdf

5. Jelev, V. (2016). "Romanian Tourism Marketing Researches." Annals of Spiru Haret University. Economic Series, http://anale.spiruharet.ro/index.php/economics/article/ view/1634/pdf

6. Li, J. J., \& Xu, L. (2018). "Big Data in Tourism Research: A Literature Review." Tourism Management Journal, https://doi.org/10.1016/j.tourman.2018.03.009

7. Marques, J. (2017). "Tourism Development Strategies for Business Tourism Destinations: Case Study in the Central Region of Portugal (SCOPUS).” Tourism: International Scientific and Professional Journal, https://hrcak.srce.hr/191475

8. Mehran, J., \& Olya, H. (2018). "Progress on Outbound Tourism Expenditure Research: A Review." Current Issues in Tourism, https://doi.org/10.108/13683500.2018.1517734

9. Seabra, C., \& Kastenholz, E. (2018). "Peacefulness at Home: Impacts on International Travel.” International Journal of Tourism Cities, https://www.emeraldinsight.com/ doi/abs/10.1108/IJTC-10-2017-0050.

10. Song, H., \& Li, G. (2018). "Tourism and Economic Globalization: An Emerging Research Agenda.” Journal of Travel Research, https://doi.org/10.1177/0047287517734943

11. World Economic Forum (2018). "These Three Technology Trends Will Change the Way You Travel," accessed November 10, 2018, https://www.weforum.org/agenda/2018/06/threetechnology-trends-changing-travel-tourism/

12. World Travel and Tourism Council (2018). "Economic Impact 2018 World,” accessed November 9, 2018, https://www.wttc.org/-/media/files/reports/economic-impact-research/ regions 2018/world2018.pdf

13.Zach, F., \& Hill, T. L. (2017). "Network, Knowledge and Relationship Impacts on Innovation in Tourism Destinations.” Tourism Management Journal, https://doi.org/ 10.1016/j.tourman.2017.04.001. 
